\title{
PEMANFAATAN LAHAN PEKARANGAN UNTUK PENANAMAN TOGA DI DESA JATIKALANG KECAMATAN KRIAN KABUPATEN SIDOARJO
}

\author{
Rhenny Ratnawati ${ }^{1 *}$, Sri Widyastuti ${ }^{1}$, Pungut ${ }^{1}$ \\ ${ }^{1}$ Program Studi Teknik Lingkungan, Universitas PGRI Adi Buana Surabaya, Indonesia \\ *Email: ratnawati@unipasby.ac.id
}

\begin{abstract}
Informasi Artikel Abstrak
Kata kunci:

COVID-19, Lahan

Pekarangan, TOGA

Diterima: 16-07-2021

Disetujui: 05-01-2022

Dipubikasikan: 28-01-

2022

Usaha untuk mencegah penularan COVID 19 dapat dilakukan dengan menggunakan masker, menjaga jarak, mencuci tangan menggunakan sabun menggunakan handsanitizer dan lain sebagainya. Menjaga kesehatan tubuh agar terhindar dari COVID 19 salah satunya dengan menjaga imun tubuh dengan mengkonsumsi obat herbal/obat tradsional atau suplemen kesehatan. Kunyit, jahe, temulawak, meniran, jambu biji, sambiloto merupakan Tanaman obat keluarga (TOGA) yang berfungsi untuk meningkatkan imun. Tujuan dari kegiatan pengabdian pada masyarakat ini adalah pengetahuan tentang pemanfaatan lahan pekarangan yang dapat dibuat sebagai taman TOGA. Metode pelaksanaan pengabdian diawali dari survey lokasi, penyuluhan dan monitoring serta evaluasi. Hasil dari kegiatan ini adalah masyarakat memperoleh, pengetahuan dan kertampilan serta kesadaran untuk memanfaatkan lahan sebagai lahan tanaman TOGA. Hal itu ditandai dengan lingkungan yang terlihat asri dan beberapa sudah mulai memanen TOGA seperti apa yang mereka tanam. Selain itu warga desa sudah bisa menikmati hasil akhir yang dihasilkan yaitu berupa produk jamu dan bumbu dapur yang digunakan sebagai kebutuhan pribadi.
\end{abstract}

Keywords :

COVID-19, Yard Land, TOGA 


\section{PENDAHULUAN}

Pada Bulan Maret 2020 bangsa Indonesia hingga saat ini mengalami pandemi COVID 19. Masyarakat diharapkan menyadari akan pentingnya menjaga kesehatan. Usaha untuk mencegah penularan COVID 19 dapat dilakukan dengan menggunakan masker, menjaga jarak, mencuci tangan menggunakan sabun menggunakan handsanitizer dan lain sebagainya (Ode et al. 2020). Menjaga kesehatan tubuh agar terhindar dari COVID 19 salah satunya dengan menjaga imun tubuh dengan mengkonsumsi obat herbal/obat tradsional atau suplemen kesehatan. Kunyit, jahe, temulawak, meniran, jambu biji, sambiloto merupakan Tanaman obat keluarga (TOGA) yang berfungsi untuk meningkatkan imun (Ode et al. 2020).

TOGA merupakan tanaman yang di tanam di sekitar rumah dan berfungsi sebagai apotik hidup yang dapat digunakan sebagai obat keluarga (Harfiani, Anisah, dan Agneta 2014). Toga dapat ditanam di pekaranga, pot atau polybag. Obat dengan bahan baku herbal dapat dijumpai disekitar kita (Susanto 2017). TOGA mengandung beberapa senyawa antara lain flavonoid, tanin, alkaloid, terpenoid yang berfungsi sebagai senyawa aktif dalam obat (Harfiani et al. 2014). Kandungan senyawa kimia alami dalam TOGA mempunyai efek farmakologis dan bioaktivitas, baik sebagai anti penyakit infeksi sampai penyakit degeneratif, seperti hepatitis, arthritis, kanker sehingga dapat digunakan sebagai obat (Harfiani et al. 2014). Selain sebagai obat, TOGA juga bermanfaat sebagai: (1) penambah gizi keluarga, seperti bayam, timun, papaya; (2) bumbu dapur seperti jahe, kunyit, kencur, bawang merah, bawang putih, sereh, daun salam; (3) tanaman hias, seperti bunga mawar, melati, tapak doro, kumis kucing, kembang sepatu (Nurdiwaty et al. 2017).

Desa Jatikalang merupakan desa yang cukup besar dengan luas wilayah sekitar $1.550 .000 \mathrm{~m}^{2}$ serta Desa Jatikalang mempunyai jumlah penduduk sebesar 5.314 jiwa yang terdiri dari penduduk laki-laki sebanyak 2.655 jiwa dan pendudukan perempuan sebanyak 2.659 jiwa. Pemerintah Desa Jatikalang sudah menyediakan lahan desa untuk dijadikan kebun bibit TOGA dengan harapan hasil TOGA dapat dijadikan produk unggulan desa. Tetapi keinginan Desa untuk dapat menghasilkan produk unggulan belum tercapai, karena kebun kurang terawatt sehingga belum mendapatkan hasil panen yang optimal. Kebun bibit TOGA Desa Jatikalang dapat dilihat pada Gambar 1.

Pekarangan adalah taman rumah tradisional yang bersifat pribadi, yang merupakan sistem terintegrasi berhubungan erat antara manusia, tanaman, dan hewan. Pekarangan juga merupakan ruang terbuka yang sering dimanfaatkan untuk acara kekerabatan dan kegiatan sosial (Wurianingsih 2011). Menurut Rahayu dkk (2005) pemanfaatan TOGA telah dilakukan secara efektif dengan memadukan tanaman tahunan dengan tanaman semusim. Lahan pekarangan memiliki fungsi multiguna, karena dari lahan yang relatif sempit dapat menghasilkan bahan pangan seperti umbiumbian, sayuran, buah-buahan; bahan tanaman rempah dan obat, bahan kerajinan tangan; serta bahan pangan hewani yang berasal dari unggas, ternak kecil maupun ikan. Menurut Kristanti (2011) 
pekarangan rumah memiliki berbagai fungsi sesuai peruntukannya. Manfaat yang diperoleh dari pengelolaan pekarangan antara lain dapat: memenuhi kebutuhan konsumsi dan gizi keluarga, menghemat pengeluaran, dan dapat memberikan tambahan pendapatan bagi keluarga.
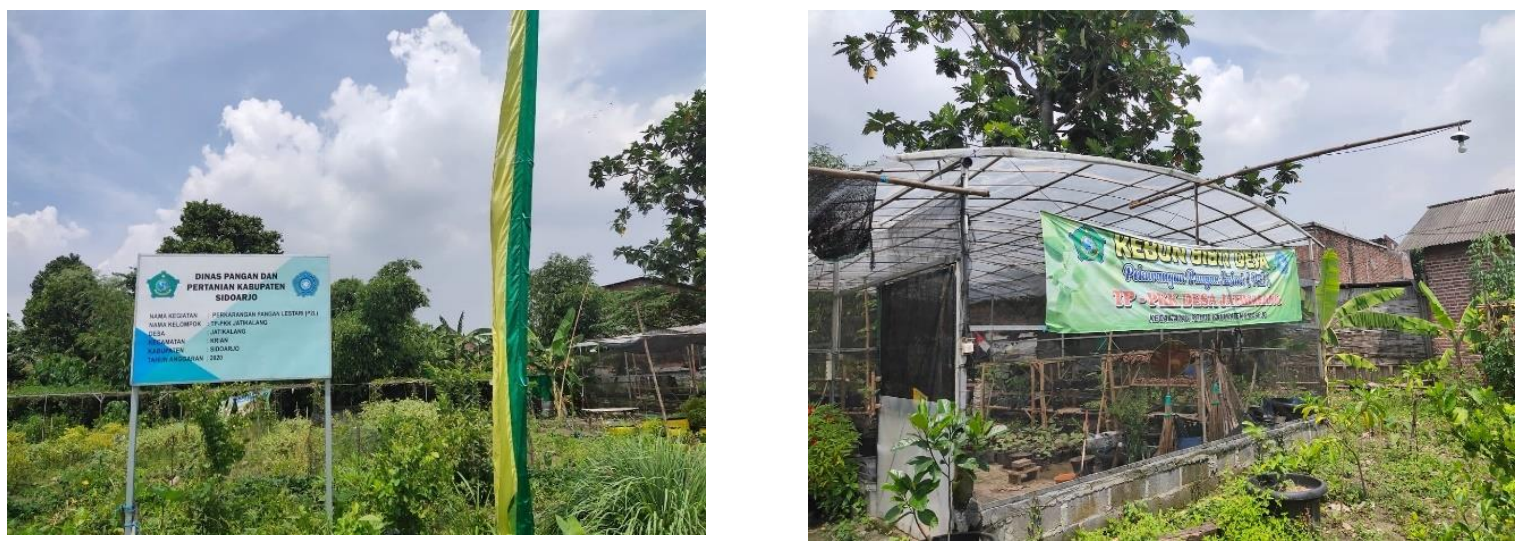

Gambar 1 Kebun Bibit TOGA Desa Jatikalang

Sebagian besar lahan pekarangan yang ada di Desa Jatikalang belum termanfaatkan secara optimal untuk meningkatkan kebutuhan hidup masyarakat terutama sebagai penunjang perekonomian dan sebagai tanaman obat keluarga. Warga sebagian besar hanya mengandalkan mata pencaharian hasil pertanian saja. Minimnya fasilitas dan informasi bagi masyarakat terutama golongan masyarakat menengah ke bawah menyebabkan pemanfaatan toga masih kurang dirasakan (Misfadhila et al. 2018)

Pembangunan kesehatan yang berkelanjutan akan tercapai secara optimal dengan peran serta masyarakat dalam pengelolaan pengobatan tradisional (Karamina et al. 2020). Oleh karena itu sangat perlu dilakukan optimalisasi pemanfaatan lahan pekarangan untuk taman TOGA dan sekaligus untuk berwirausaha dengan memanfaatkan hasil tanaman yang telah diproduksi. Salah satu diantaranya adalah dengan pembuatan jamu tradisional. Selain itu, mengadakan pelatihan penanaman tanaman obat keluarga adalah salah satu cara untuk melestarikan kearifan budaya tanaman obat keluarga di Indonesia (Nugraha 2015). Melalui kegiatan ini maka diharapkan kesehatan masyarakat semakin meningkat dengan memanfaatkan TOGA. Dampak jangka panjang yang diperoleh adalah peningkatan estetika dan kesehatan lingkungan sehingga dengan meningkatnya kandungan oksigen diatmosfir akan dapat menekan terjadinya perubahan iklim. Dari berbagai permasalahan yang ada di Desa Jatikalang, permasalahan yang akan dijadikan tema dalam program PPM kali ini adalah "Pemanfaatan Lahan Pekarangan Untuk Penanaman TOGA Guna di Desa Jatikalang Kecamatan Krian Kabupaten Sidoarjo"

\section{METODE}

Kegiatan pengabdian kepada masyarakat ini dilakukan di Desa Jatikalang Kecamatan Krian Kabupaten Sidoarjo. Kegiatan pengabdian ini adalah kegiatan partisipatif masyarakat sehingga serangkaian kegiatan pengabdian mulai dari kegiatan survey lokasi, pelaksanaan, monitoring dan 
evaluasi selalu melibatkan masyarakat. Kelompok sasaran dari kegiatan pengabdian ini adalah karang taruna, bapak-bapak dan ibu -ibu PKK. Langkah-langkah kegiatan pengabdian yang dilakukan adalah sebagai berikut

a. Survey Lokasi

Persiapan survei lokasi dilakukan bersama dengan tim PPM Dosen Teknik Lingkungan Universitas PGRI Adi Buana Surabaya. Dari hasil survei tampak permasalahan yang perlu segera ditangani yaitu terdapatnya lahan yang belum diolah secara optimal sehingga hal itu membuat lahan tersebut terlihat terbengkalai. Hal ini dapat mengakibatkan rusaknya estetika lingkungan. Sekitar 80\% lahan pekarangan di Desa Jatikalang belum diberdayakan secara optimal.

b. Persiapan Sarana dan Prasarana

Setelah melakukan survey awal dan penetapan permasalahan yang akan diangkat dan diselesaikan di lokasi adalah tim PPM melakukan koordinasi dengan pihak pemerintahan desa dalam hal ini Kepala Desa Jatikalang Kecamatan Krian Sidoarjo dan kader PKK Desa Jatikalang Kecamatan Krian Sidoarjo. Selanjutnya dipilih lokasi di Balai Desa Jatikalang Kecamatan Krian Sidoarjo untuk pelaksanaan PPM ini. Pemilihan lokasi dilandasi pada posisi balai Desa Jatikalang Kecamatan Krian Sidoarjo yang berada dekat dengan beberapa dusun di desa tersebut. Persiapan sarana dan prasana di lokasi dilaksanakan oleh aparat desa, tim pelaksana PPM, dan dibantu dengan mahasiswa pembantu PPM.

c. Koordinasi dengan Pemerintah Desa

Koordinasi dengan pemerintahan desa bertujuan menentukan jadwal kegiatan PPM dan kegiatan mendapatkan dukungan dari pemerintah desa. Kegiatan PPM dilaksanakan di balai Desa Jatikalang. Peserta yang akan diikutkan kegiatan PPM adalah ibu-ibu anggota PKK.

d. Persiapan Alat dan Bahan

Proses pengadaan alat dan bahan oleh tim pelaksana PPM sepenuhnya telah disiapkan oleh tim dosen dan dibantu oleh mahasiswa pembantu PPM. Bahan utama yang diapkan dalam kegiatan ini merupakan alat lengkap berkebun dan beberapa benih tanaman TOGA. Alat dan benih tanaman kemudian akan diserahkan ke warga desa untuk dimanfaatkan oleh kelompok ibu PKK. Alat yang dibutuhkan telah disiapkan oleh tim dosen di prodi Teknik Lingkungan Universitas PGRI Adi Buana Surabaya.

e. Penyuluhan dan Pelatihan

Penyuluhan dilakukan dengan tema besarnya adalah pemanfaatan lahan rumah tangga untuk penanaman TOGA di masa pandemic COVID-19. Disamping mensosialisasikan cara memanfaatkan lahan, masyarakat juga melakukan simulasi secara langsung untuk menanam benih 
tanaman TOGA. Produk akhir yang dihasilkan diharapkan nanti akan menunjang kesehatan dan perekonomian masyarakat Desa Jatikalang Kecamatan Krian Sidoarjo.

Penyuluhan dan pelatihan tentang pemanfaatan lahan kosong di Desa Jatikalang Kecamatan Krian Sidoarjo dilaksanakan dalam masa pandemic Covid-19, sehingga pelaksanannya menerapkan protokoler kesehatan yang ketat. Warga yang diundang hanya 25\% dari kapasitas ruang Balai Desa Jatikalang sehingga sosial distancing dapat dijaga. Ruang balai desa yang digunakan untuk penyuluhan dan praktik merupakan joglo dengan semua sisinya terbuka sehingga sirkulasi udara sangat bagus. Tamu undangan dan tim PPM sebelum masuk ruangan harus menggunakan masker dan hand sanitizer.

Sebelum penyuluhan peserta diberikan soal pre tes, yang bertujuan untuk mengetahui tingkat pemahaman warga masyarakat terhadap pemanfaatan lahan untuk penanaman TOGA. Penyuluhan diawali dengan sambutan Ketua Prodi Teknik Lingkungan. Dengan adanya penyuluhan pemanfaatan lahan untuk penanaman TOGA, maka diharapkan dapat menumbuhkan kesadaran warga akan pentingnya kelestarian lingkungan dan kesehatan terutama pada masa pandemik saat ini.

Penyuluhan dilakukan dalam 1 sesi sekaligus, dimana pada sesi tersebut yaitu tentang pengenalan tanaman TOGA dan bagaimana cara memanfaatkan lahan dengan baik dan benar yang dipandu oleh tim dosen PPM serta beberapa mahasiswa Teknik Lingkungan. Langkah akhir dari kegiatan PPM adalah mengukur keberhasilan program yaitu dengan menggunakan post tes. Materi pre tes dan post sama. Foto kegiatan PPM dapat dilihat pada Gambar 2.

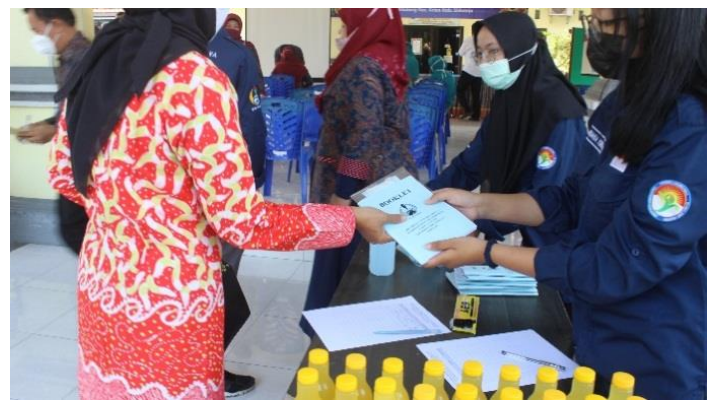

a. Peserta mengisi daftar hadir

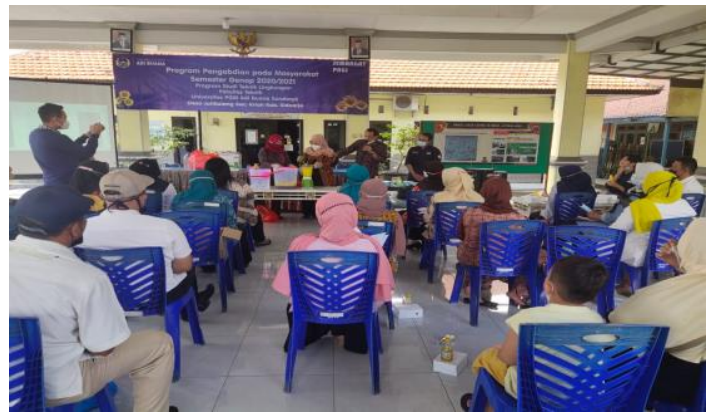

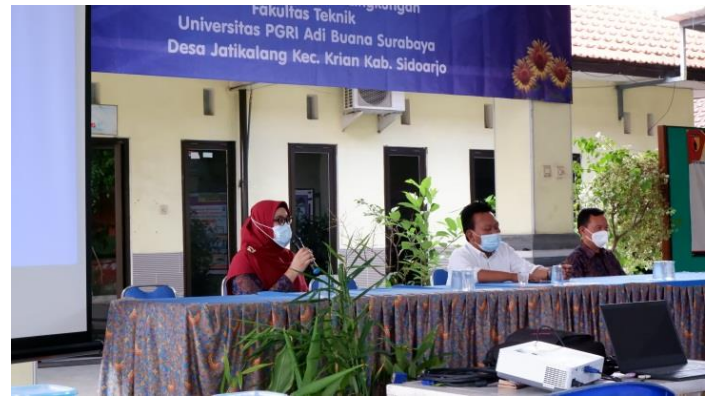

b. Sambutan oleh kaprodi dan kepala desa

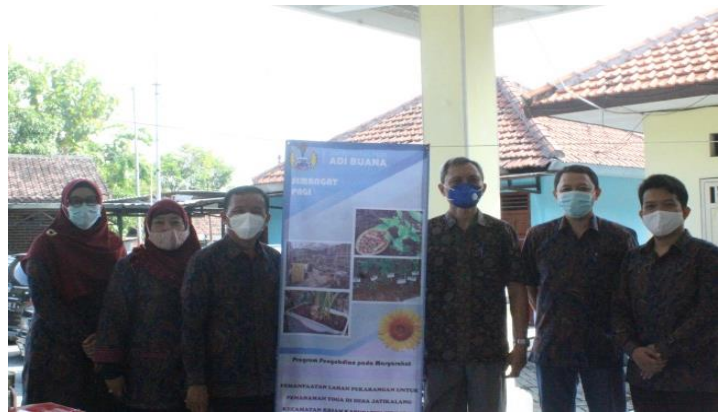


c. Peserta kegiatan PPM

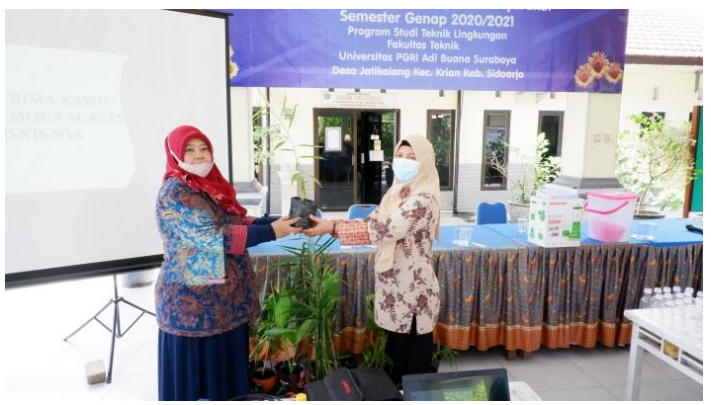

e. Penyerahan bibit tanaman toga d. Tim PPM

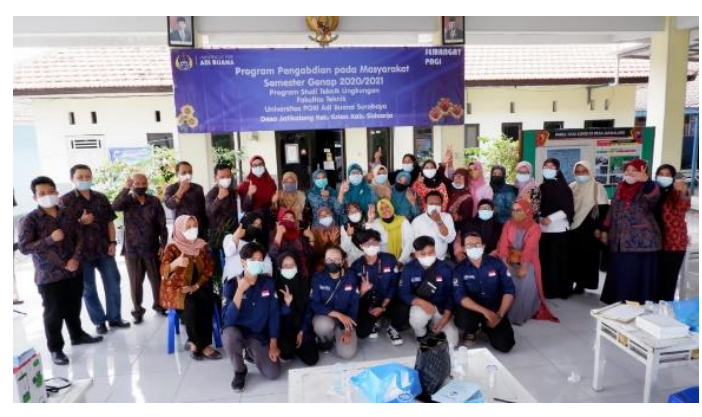

f. Tim PPM dan peserta

Gambar 2. Kegiatan PPM Di Desa Jatikalang

\section{HASIL DAN PEMBAHASAN}

Hasil pelaksanaan PPM ini adalah sebagai berikut:

1. Kondisi Awal

Dilihat dari kondisi awalnya, masyarakat Desa Jatikalang Kecamatan Krian Sidoarjo sebagaian sudah pernah menanam tanaman TOGA pada lingkungan rumahnya. Secara garis besar dari isian quisioner menunjukan bahwa sebagian besar masyarakatnya belum pernah memanfaatkan lahannya untuk tanaman TOGA. Hasil isian quisioner sebelum dilakukan penyuluhan dan pelatihan ditunjukan pada Tabel 1.

Tabel 1. Hasil Kuisioner Sebelum Dilakukan Penyuluhan Dan Pelatihan

\begin{tabular}{|c|l|c|c|}
\hline \multirow{2}{*}{ No } & \multicolumn{1}{|c|}{ Pertanyaan } & \multicolumn{2}{c|}{ Presentase (\%) } \\
\cline { 3 - 4 } 1. & $\begin{array}{l}\text { Apakah warga masyarakat di Desa Jatikalang sudah memanfaatkan lahan } \\
\text { pekarangan untuk tanaman TOGA sebagai obat keluarga? }\end{array}$ & 69,0 & 31,0 \\
\hline 2. & Apakah Bapak Ibu telah mengetahui manfaat menanam TOGA? & 79,3 & 20,7 \\
\hline 3. & Apakah semua jenis lahan dapat di tanami TOGA? & 82,8 & 17,2 \\
\hline 4. & $\begin{array}{l}\text { Apakah warga masyarakat tahu bahwa budi daya tanaman TOGA harus secara } \\
\text { organik? }\end{array}$ & 51,7 & 48,3 \\
\hline 5. & $\begin{array}{l}\text { Apakah pemerintah desa sudah memberikan pelatihan tentang cara } \\
\text { Pemanfaatan Lahan Pekarangan Untuk Penanaman TOGA? }\end{array}$ & 34,5 & 65,5 \\
\hline 6. & $\begin{array}{l}\text { Apakah sudah ada instansi atau universitas lain yang sudah memberikan } \\
\text { pelatihan tentang cara Pemanfaatan Lahan Pekarangan Untuk Penanaman } \\
\text { TOGA? }\end{array}$ & - & 100,0 \\
\hline 7. & Apakah Bapak Ibu telah mengetahui kriteria bibit unggul TOGA? & 3,4 & 96,6 \\
\hline
\end{tabular}




\begin{tabular}{|c|c|c|c|}
\hline \multirow{2}{*}{ No } & \multirow{2}{*}{ Pertanyaan } & \multicolumn{2}{|c|}{ Presentase $(\%)$} \\
\hline & & $\mathrm{Ya}$ & Tidak \\
\hline 8. & $\begin{array}{l}\text { Apakah sore hari waktu yang tepat untuk memindahkan bibit TOGA ke lahan } \\
\text { tanam? }\end{array}$ & 82,8 & 17,2 \\
\hline 9. & $\begin{array}{l}\text { Apakah sistem penanaman dengan bedengan dan mulsa adalah sistem } \\
\text { penanaman TOGA yang baik? }\end{array}$ & 79,3 & 20,7 \\
\hline 10 & Apakah bapak ibu tertarik untuk memanfaatkan lahan dengan menanam TOGA? & 100,0 & - \\
\hline \multirow{3}{*}{11} & \multicolumn{3}{|l|}{ Berkaitan dengan soal No. 10 mohon diberikan alasan } \\
\hline & \multicolumn{3}{|l|}{$\begin{array}{l}\text { Mengapa tertarik untuk menanam TOGA? } \\
\text { 1. Karena berguna sebagai bahan baku pembuatan jamu }\end{array}$} \\
\hline & \multicolumn{3}{|l|}{$\begin{array}{l}\text { Apabila tidak tertarik, apa alasan nya? } \\
\text { 1. Lahan tidak memadai } \\
\text { 2. Tidak ada waktu karena sibuk mengurus rumah } \\
\text { 3. Tidak tahu cara menanam yang baik dan benar }\end{array}$} \\
\hline
\end{tabular}

Dapat dilihat pada kuisioner sebelum dilakukan penyuluhan, sebagaian masyarakat kurang tertarik menanam toga dikarenakan beberapa alasan yaitu lahan di pekarangan rumah yang tidak memadai, masyarakat sudah mempunyai kesibukan sehingga beranggapan bahwa tidak ada waktu untuk menanam toga dan tidak mengerti cara menanam yang baik dan benar.

2. Kondisi Akhir

Setelah dilakukan penyuluhan dan pelatihan terkait dengan pemanfaatan lahan perkarangan untuk tanaman TOGA, maka diperoleh hasil yang maksimal. Secara umum setelah 2 minggu pelaksanaan penyuluhan dan pelatihan sebagian besar masyarakatnya menerapkan apa yang didapatkan selama palatihan. Hal ini dapat dilihat dari hasil isian quisioner setelah dilakukan penyuluhan dan pelatihan seperti pada Tabel 2 .

Tabel 2. Hasil Kuisioner Setelah Dilakukan Penyuluhan Dan Pelatihan

\begin{tabular}{|c|l|c|c|}
\hline \multirow{2}{*}{ No } & \multicolumn{1}{|c|}{ Pertanyaan } & \multicolumn{2}{|c|}{ Presentase (\%) } \\
\cline { 3 - 4 } 1. & $\begin{array}{l}\text { Apakah warga masyarakat di Desa Jatikalang sudah meman-faatkan lahan } \\
\text { pekarangan untuk tanaman TOGA sebagai obat keluarga? }\end{array}$ & 69,0 & 31,0 \\
\hline 2. & Apakah Bapak Ibu telah mengetahui manfaat menanam TOGA? & 100,0 & 0,0 \\
\hline 3. & Apakah semua jenis lahan dapat di tanami TOGA? & 93,1 & 6,9 \\
\hline 4. & $\begin{array}{l}\text { Apakah warga masyarakat tahu bahwa budi daya tanaman TOGA harus secara } \\
\text { organik? }\end{array}$ & 58,6 & 41,4 \\
\hline 5. & $\begin{array}{l}\text { Apakah pemerintah desa sudah memberikan pelatihan tentang cara } \\
\text { Pemanfaatan Lahan Pekarangan Untuk Penanaman TOGA? }\end{array}$ & 34,5 & 65,5 \\
\hline 6. & $\begin{array}{l}\text { Apakah sudah ada instansi atau universitas lain yang sudah memberikan } \\
\text { pelatihan tentang cara Pemanfaatan Lahan Pekarangan Untuk Penanaman } \\
\text { TOGA? }\end{array}$ & 62,1 & 37,9 \\
\hline
\end{tabular}




\begin{tabular}{|c|c|c|c|}
\hline \multirow{2}{*}{ No } & \multirow{2}{*}{ Pertanyaan } & \multicolumn{2}{|c|}{ Presentase $(\%)$} \\
\hline & & $\mathrm{Ya}$ & Tidak \\
\hline 7. & Apakah Bapak Ibu telah mengetahui kriteria bibit unggul TOGA? & 44,8 & 55,2 \\
\hline 8. & $\begin{array}{l}\text { Apakah sore hari waktu yang tepat untuk memindahkan bibit TOGA ke lahan } \\
\text { tanam? }\end{array}$ & 65,5 & 34,5 \\
\hline 9. & $\begin{array}{l}\text { Apakah sistem penanaman dengan bedengan dan mulsa adalah sistem } \\
\text { penanaman TOGA yang baik? }\end{array}$ & 100,0 & - \\
\hline 10 & Apakah bapak ibu tertarik untuk memanfaatkan lahan dengan menanam TOGA? & 100,0 & - \\
\hline 11 & \multicolumn{3}{|l|}{ Berkaitan dengan soal No. 10 mohon diberikan alasan } \\
\hline 11 & \multicolumn{3}{|l|}{$\begin{array}{l}\text { Mengapa tertarik untuk menanam TOGA? } \\
\text { 1. Karena berguna sebagai bahan baku pembuatan jamu } \\
\text { 2. Mengurangi pengeluaran bahan dapur } \\
\text { 3. Dapat diambil ketika sewaktu-waktu dibutuhkan } \\
\text { 4. Mengisi waktu luang } \\
\text { 5. Menjadikannya sebagai ladang usaha }\end{array}$} \\
\hline & \multicolumn{3}{|l|}{$\begin{array}{l}\text { Apabila tidak tertarik, apa alasan nya? } \\
\text { 1. Lahan tidak memadai }\end{array}$} \\
\hline
\end{tabular}

Pada kuisioner di atas, respon masyarakat setelah dilakukan penyuluhan semakin baik. Warga menjadi terbuka akan peluang keuntungan menanam TOGA karena sudah mendapatkan ilmu tentang bagaimana cara menanam TOGA. Adapun beberapa alasan warga mulai tertarik adalah karena berguna sebagai pembuatan jamu sehingga dapat dijadikan sebagai konsumsi pribadi maupun lading usaha, mengisi waktu luang dan menjadi bahan dapur serta untuk kebutuhan mendesak yang bersifat pribadi

\section{KESIMPULAN}

Pelaksanaan Pengabdian Pada Masyarakat (PPM) berupa IbM Pemanfaatan Lahan Pekarangan Untuk Penanaman TOGA di Desa Jatikalang Kecamatan Krian Kabupaten Sidoarjo berjalan dengan baik. Hasil yang diperoleh dari pelaksanaan ini adalah kelestarian lingkungan pemanfaatan lahan yang sudah optimal untuk tanaman TOGA. Warga Desa Jatikalang Kecamatan Krian Sidoarjo sudah mulai merasakan apa yang telah mereka kerjakan yaitu lingkungan terlihat asri dan beberapa sudah mulai memanen TOGA seperti apa yang mereka tanam. Selain itu warga desa sudah bisa menikmati hasil akhir yang dihasilkan yaitu berupa produk jamu dan bumbu dapur yang digunakan sebagai kebutuhan pribadi.

\section{UCAPAN TERIMAKASIH}

Ucapan terima kasih penulis sampaikan kepada kasih kepada LPPM UNIPA Surabaya yang telah membiayai pekalsanaan kegiatan PPM ini, pemerintahan Desa yang telah memberikan ijin untuk kegiatan ini dan warga Desa Jatikalang yang telah berpartisipasi aktif dalam kegiatan ini sehingga kegiatan PPM ini berjalan lancar. 


\section{DAFTAR PUSTAKA}

Harfiani, Erna, Anisah, and Irmarahayu Agneta. 2014. "Pemberdayaan Masyarakat Rw 03 Depok Jaya Dalam Memanfaatkan Toga Di Lahan Pekarangan Rumah Sebagai Minuman Kesehatan." Seminar Hasil Pengabdian Kepada Masyarakat 2.

Karamina, Hidayati, Supriyadi Supriyadi, Dudella Desnani Firman Yasin, Muhammad Yusi Kamhar, and Farida Kusuma Astuti. 2020. "Pemanfaatan Dan Penanaman Tanaman Obat Keluarga (TOGA) Menuju Keluarga Sehat Pada Ibu Pemberdayaan Kesejahteraan Keluarga (PKK)." JIPEMAS: Jurnal Inovasi Hasil Pengabdian Masyarakat 3(2):120. doi: 10.33474/jipemas.v3i2.6416.

Kristanti, I. 2011. "Optimalisasi Pemanfaatan Pekarangan Menjadi Taman Sayur Yang Produktif."

Misfadhila, Sestry, Zikra Azizah, Rusdi, and cynthia diane Putri Chaniago. 2018. "Pengaplikasian Cangkang Telur Dan Karbon Aktif Sebagai Adsorben Logam Timbal.” Farmasi Higea 10(2):18.

Nugraha, Sumedi P. 2015. "Pelatihan Penanaman Tanaman Obat Keluarga (Toga)." Asian Journal of Innovation and Entrepreneurship 4(Vol 4, No 01 (2015): January 2015):58-62.

Nurdiwaty, Diah, Erna Puspita, Dian Kusumaningtyas, and Puji Winarko. 2017. "Diah Nurdiwaty 1 , Erna Puspita 2 Dkk PEMBERDAYAAN WANITA MELALUI TANAMAN TOGA UNTUK MEMBANTU MENINGKATKAN PENDAPATAN KELUARGA.” Jurnal ABDINUS 1(1):2027.

Ode, La, Muhammad Fitrawan, Asniar Pascayantri, Andi Nafisah, and Tendri Adjeng. 2020. "Sosialisasi Dan Edukasi Pemanfaatan Tanaman Berkhasiat Obat Dalam Menghadapi Masa Pandemi COVID-19 Di Kota Kendari Socialization and Education Of Effective Medicine Plants In Facing COVID-19 Pandemic in Kendari City COVID-19 Berkasiat Obat Sulawesi Tengga." $1(2)$.

Rahayu, M. \&. Prawiroatmojo. 2005. "Keanekaragaman Tanaman Pekarangan Dan Pemanfaatannya Di Desa Lampeapi, Pulau Wawoni, Sulawesi Selatan.” Jurnal Teknologi Lingkungan P3TLBPPT 6(1):111-117.

Susanto, Agus. 2017. "Komunikasi Dalam Sosialisasi Tanaman Obat Keluarga (TOGA) Di Kecamatan Margadana." Jurnal Para Pemikir 6(1):111-17.

Wurianingsih, Mega. 2011. "Studi Karakteristik Dan Fungsi Pekarangan Di Desa Pasir Eurih Kecamatan Taman Sari Kabupaten Bogor.” Skripsi IPB. Bogor. 